\title{
Challenges and Potential Solutions for Sustainable Urban-Rural Linkages in a Ghanaian Context
}

\author{
Albert Novas Somanje ${ }^{1}$, Geetha Mohan ${ }^{1,2}$, Julia Lopes ${ }^{1}$ (i), Adelina Mensah ${ }^{3}{ }^{(1)}$, \\ Christopher Gordon ${ }^{3}{ }^{(0)}$, Xin Zhou ${ }^{4}$, Mustafa Moinuddin ${ }^{4}$, Osamu Saito ${ }^{1,4, *(1)}$ and \\ Kazuhiko Takeuchi ${ }^{2,4}$ \\ 1 United Nations University Institute for the Advanced Study of Sustainability (UNU-IAS), Tokyo 150-8925, \\ Japan; somanje@gmail.com (A.N.S.); geethamohanmsc@outlook.com (G.M.); lopesjulia@gmail.com (J.L.) \\ 2 Institute for Future Initiatives (IFI), The University of Tokyo, Tokyo 133-8654, Japan; \\ takeuchi@ifi.u-tokyo.ac.jp \\ 3 Institute for Environment and Sanitation Studies, College of Basic and Applied Sciences, University of \\ Ghana (UG), Accra LG 209, Ghana; ammensah@staff.ug.edu.gh (A.M.); cgordon@staff.ug.edu.gh (C.G.) \\ 4 Institute for Global Environmental Strategies (IGES), Kanagawa 240-0115, Japan; Zhou@iges.or.jp (X.Z.); \\ moinuddin@iges.or.jp (M.M.) \\ * Correspondence: o-saito@iges.or.jp; Tel.: +81-468747621
}

Received: 5 December 2019; Accepted: 7 January 2020; Published: 9 January 2020

\begin{abstract}
Urban-rural linkages are an integral part of fostering development in both urban and rural communities. However, the focus on development tends to have an urban bias toward Sub-Saharan Africa (SSA) with an increase in urbanization. Ghana is one of the fastest urbanizing countries in SSA. This paper sought to identify the challenges of urban-rural linkages, their corresponding solutions, and contributions to Agenda 2030 that are context-specific to Ghana through a stepwise solution scanning technique. In step 1 , the study applied a scoping process to identify the urban-rural challenges. In step 2, a solution for the identified urban-rural challenges in step 1 was co-designed. In step 3, each identified solution was assessed based on its potential to contribute to all three pillars of sustainability by ranking and prioritization. In step 4, the Sustainable Development Goals (SDGs) interlinkages of the top five prioritized potential solutions were analyzed. The identified challenges were (1) inequality and gender gaps, (2) poor and lack of basic and economic infrastructures, (3) the limited effectiveness of decentralization, and (4) food and nutrition security dynamics. The prioritized potential solutions were gender inclusiveness, investment in infrastructures, sustainable agricultural systems, effective decentralization, and financial inclusion. This study recommends maximizing the synergies and minimizing the trade-offs between the SDGs of the potential solutions identified.
\end{abstract}

Keywords: urban-rural linkages; potential solutions; sustainable development; sub-Saharan Africa; Ghana

\section{Introduction}

Sub-Saharan Africa (SSA) has 40\% urban and 60\% rural population and it has the fastest growing rate of urbanization globally according to the United Nations Department of Economic and Social Affairs [1]. It is projected that $56 \%$ of SSA will be urbanized by 2050 [1]. Urbanization should be well managed and planned to reduce any negative impacts on development [2]. For SSA, increasing urbanization, coupled with the challenges of population increase, climate change, food insecurity, unemployment, and weak economic growth, affects urban-rural linkages and sustainable development [3-7]. Slum conditions remain as high as $56 \%$, owing to the high rate of urbanization in SSA [8]. Rural-urban migration is the primary driver of urbanization [9-15]. For example, the 
urbanization level in Ghana increased by 7 percent points over a 10 -year period, from $43.8 \%$ in 2000 to $50.9 \%$ in 2010 [16], with the population surpassing 24.5 million [16]. In such circumstances, a country's development focus tends to be urban biased, with rural areas often being neglected [17-20]. In addition, the poverty levels remain high. Half of the world's populace living on $\$ 1.90$ per day are in SSA. The social protection schemes in SSA are the lowest in the world at 13\%, as compared to the world average of $45 \%$ [9]. SSA and Asia make up $63 \%$ of the world's food and nutrition insecure population [9]. Furthermore, the International Monetary Fund [21] suggests that Ghana and many other SSA countries may not achieve their Sustainable Development Goals (SDGs) because of increased debt, which is projected to be more than $50 \%$ of the Gross Domestic Product. Sustainable development requires a holistic approach that takes social, economic, and environmental factors into consideration $[22,23]$ to address the challenges that affect urban-rural linkages, as conceptualized in Figure 1. Rural development is a process of improving the economic wellbeing of the population whose livelihood is dependent on primary industry, such as agriculture and natural resources $[2,5,7]$. Rural areas require the provision of non-agricultural goods and service, and diversified income sources, increased agriculture production, and retain the agricultural labor force $[2,5,7]$. On the other hand, secondary industry, such as value addition and services, with increased importation of good, and population expansion from rural migrants, characterize urban development [2,5,7]. Urban-rural linkages are spatial flows of individuals, natural, and financial resources, goods, services, and social and cultural values between urban and rural areas $[2,5]$. Urban-rural linkages offer improved equitable access to assets i.e. land, expanded markets for input and output, increased income, and diversified goods and services for sustainable urban-rural development [2,5].

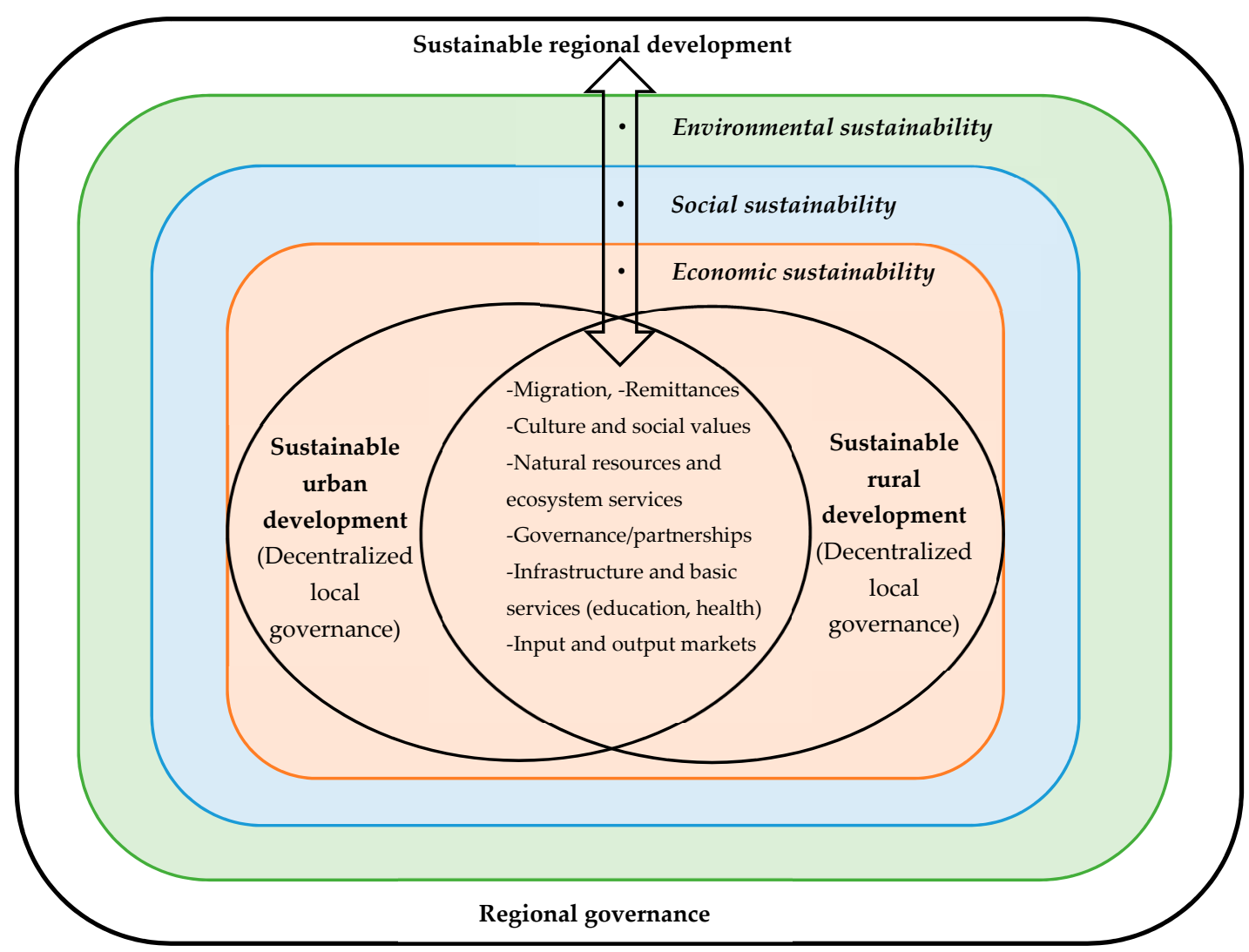

Figure 1. Conceptual framework for sustainable urban-rural linkages. Source: Authors (2019).

Rural-urban migration is vital for developing societies [13,14] and it is essential for the development of sectors beyond agriculture [2]. Rural-urban migration is the movement of people from rural to urban communities for livelihood and labor markets [2]. There are many causes of migration, which include 
decolonization [10], climate change [10], and economic challenges [7,13]. In Ghana, migrants account for $48.6 \%$ of the total population. Of the migrant population, $50.1 \%$ are female and $46.6 \%$ are male [24]. Over $50 \%$ of the population in Ghana live in urban areas [25], and this figure is expected to increase to $70 \%$ by 2050 [1]. The southern part of the country is urbanized in comparison to the northern areas [25]. Migration, poverty, and urbanization have multiple and multidimensional interlinkages that drive and influence each other in Ghana [12]. Studies in Ghana have shown that extreme poverty can lead to migration in search of a preferred livelihood strategy for household well-being [12,26,27]. However, migration for economic empowerment does not always result in economic development or poverty alleviation $[7,12,13,25]$. In some cases, migration might increase the levels of poverty [7]. The National Development Planning Commission of Ghana recognizes the prevalence of poverty in urban areas [25]. The rural non-agriculture economy (trade and mining) and secondary towns reduce poverty at a faster rate and provide more inclusive growth for migrants when compared to bigger cities [2,28]. However, Imai et al. [7] argued that the focus for development should be in rural areas rather than in urban centers to reduce poverty. In this study, we take a holistic approach to achieving sustainable development through urban-rural linkages.

Resources and services flow are significant to urban-rural linkages [3,7,29-31]. Natural resources include minerals, timber and forest products (wild foods), water, and land $[3,29,32]$. The flow of goods includes both agricultural and non-agricultural products [2]. The services include governance, infrastructure (transport, communication, and energy), health, and education [33,34]. Rural areas have poor services, and this tends to influence rural-urban migration in Ghana [35]. Rural-urban migration presents better social and economic opportunities for women, as it provides access to services and fewer cultural restrictions in Ghana [12]. Owusu [36] argued that the transfer of decision-making, services, and resources to the local level would develop growth points for sustainable rural-urban migration in Ghana.

Although urban-rural physical boundaries can be defined, governance systems, information, tradition, culture, and family ties are blurred and overlap in some cases. Cultural, traditional, and family ties can influence strong urban-rural linkages, which can facilitate sustainable social and economic development [37]. On the other hand, social relationships can be diluted by urban-rural linkages if social ties and cultural values are not preserved [37]. Social and political jurisdictional boundaries do not apply to the new commons (ecosystems services) [38], as they apply in both urban and rural areas. The urban-rural linkages concept is vital in the development of agriculture and poverty reduction [28,39], and it is critical for policy planning and implementation [40], macroeconomic policy, and poverty alleviation [34]. The role of urban-rural linkages in the New Urban Agenda includes social inclusion, opportunities for all, poverty eradication, environmental resilience, and governance [41].

The objective of this study was to identify and co-design potential solutions that could contribute to sustainable urban-rural linkages, which are vital in poverty reduction, equality, and sustainable urban and rural development $[2,7,28,41-44]$. This paper tested a methodological approach for practical operationalization of SDGs at a local level, and it sets the research agenda for vigorous assessment of the solutions relating to sustainable urban-rural development.

\section{Methodology}

This study used a solution scanning framework that was first proposed by Sutherland et al. [45]. Solution scanning is a stepwise process for policy and decision-making through the identification of a problem or challenge and an assessment of the available prioritized evidence for intervention [45]. Prioritization is applied as a filtering process by relevant stakeholders in society and it promotes transparency and contributions in decision-making [45]. The method has been applied to agroforestrybased solutions [46], conservation prioritizing and identifying needs [47,48], and the transdisciplinary co-design of scientific research agendas [49]. The methodological process was appropriate to the present study, as it can be contextualized to address the challenges of sustainable urban-rural linkages. 
The research team conducted four series of workshops with experts. The sampling of experts was purposefully affected based on stakeholders with experience and expertise in urban-rural development to ensure inter- and multidisciplinary participation [45-49]. In this study, experts (participants) were drawn from academic and research institutions (predominantly universities) and government and non-governmental organizations (Table 1).

Table 1. The discipline and composition of experts for the four series of workshop.

\begin{tabular}{|c|c|c|c|c|}
\hline \multirow{2}{*}{$\begin{array}{l}\text { Discipline of } \\
\text { Participants }\end{array}$} & \multicolumn{4}{|c|}{ Distribution of Participants } \\
\hline & $\begin{array}{l}\text { First Workshop } \\
\text { 16-17 January } 2018\end{array}$ & $\begin{array}{l}\text { Second Workshop } \\
\text { 16-17 August } 2018\end{array}$ & $\begin{array}{l}\text { Third Workshop } \\
\text { 23-24 January } 2019\end{array}$ & $\begin{array}{l}\text { Fourth Workshop } \\
\text { 17-18 March } 2019\end{array}$ \\
\hline Research core team & 3 & 3 & 2 & 3 \\
\hline \multicolumn{5}{|l|}{ Researchers/Experts } \\
\hline Environment & 3 & 10 & 12 & 13 \\
\hline Development studies & 6 & 4 & 8 & 15 \\
\hline Social studies & - & 1 & - & - \\
\hline Population studies & - & 2 & - & - \\
\hline Other & - & - & - & 3 \\
\hline \multicolumn{5}{|l|}{ Stakeholders } \\
\hline Government & - & 7 & 10 & 2 \\
\hline $\begin{array}{l}\text { Non-Governmental } \\
\text { Organizations }\end{array}$ & 2 & 3 & 2 & 3 \\
\hline Media Communications & - & 1 & 1 & 1 \\
\hline Business sector & - & 1 & 2 & 9 \\
\hline Total & 14 & 32 & 37 & 49 \\
\hline \multicolumn{5}{|l|}{ Gender distribution } \\
\hline Male & $57 \%$ & $40 \%$ & $34 \%$ & $63 \%$ \\
\hline Female & $43 \%$ & $60 \%$ & $76 \%$ & $37 \%$ \\
\hline
\end{tabular}

The government experts in Ghana were from the Ministry of Food and Agriculture, Environmental Protection Agency, Land Use, and Spatial Planning Authority, Department of Urban Road Ministry of Regional Reorganisation \& Development, NDPC, Ghana Statistical Service, National Disaster Management Organisation, and Ghana News Agency. The development organization included the Japanese International Cooperation Agency (JICA) and the Netherlands Development Organisation. Zoomlion, Eco-Management Consult, and the National Society of Black Engineers Ghana comprised the business sector. The workshop format included expert presentations, break-out group discussions, presentations of group discussions, and general discussions. A four-step methodological process framework was applied in this study (Figure 2). 


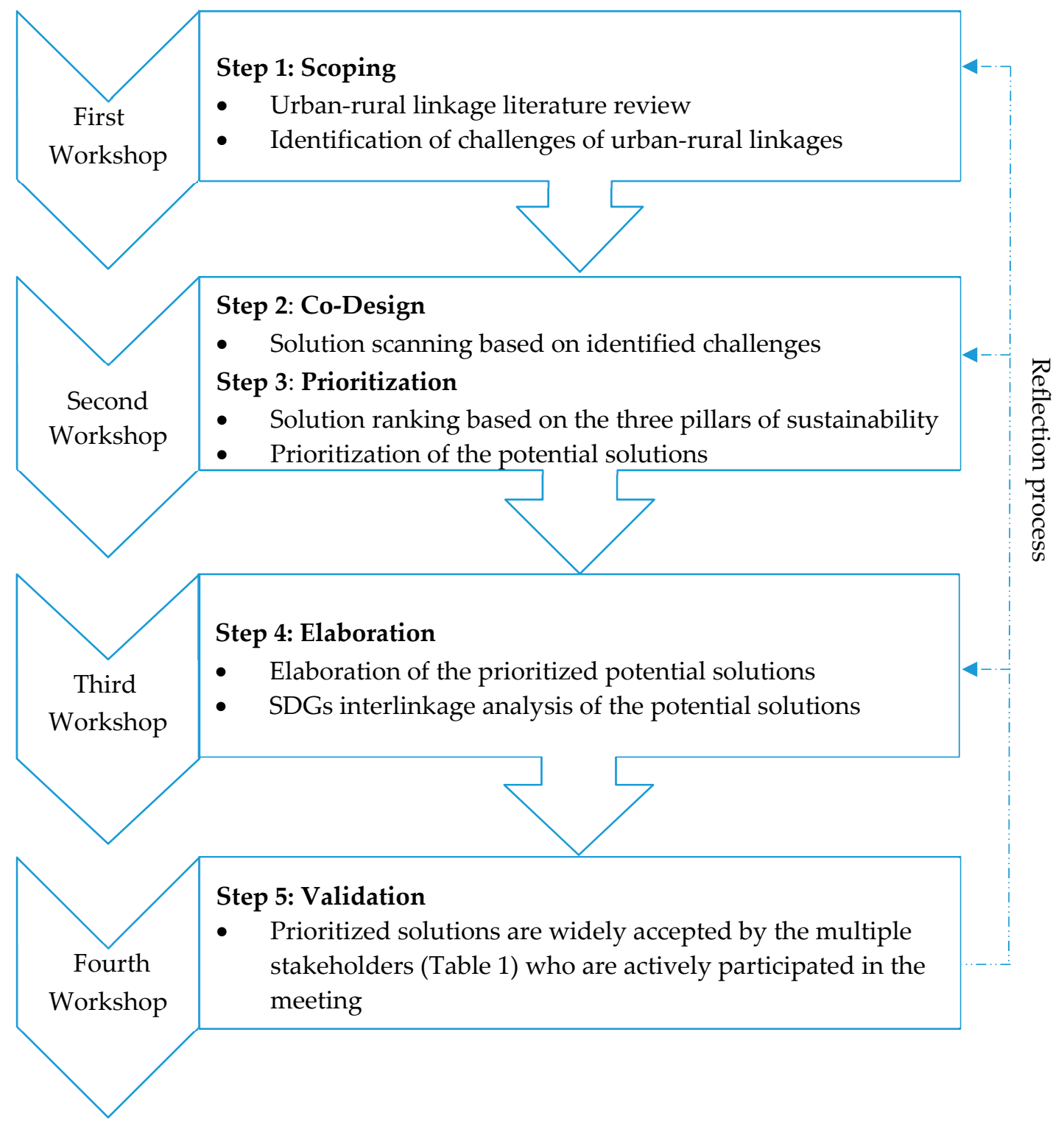

Figure 2. Summary of the methodological framework. Source: Authors (2019).

Step 1 was a scoping process and it included a literature review and identification of urban-rural challenges through an expert scoping workshop held in Tokyo, Japan, in January 2018. For the literature review, Google Scholar, Science Direct, and Scopus were used for searching the papers. "Urban-rural linkage" and "rural-urban linkage" were the search words used. Other words included "rural-urban continuum", "rural-urban development", and "rural-urban gradient". Only articles published from 2000 to 2018 were considered. The duplicates were removed, abstracts were screened, and, finally, content analysis and relevance were used as some of the inclusion and exclusion criteria. Fifty-six papers were reviewed and potential solutions were identified.

In step 2, the potential solutions identified in step 1 were screened and co-designed to suit the local context through a second workshop in Accra, Ghana, on 16-17 August 2018. The study drew potential solutions from the literature review and expert opinions during the second workshop to create the final list of potential solutions (Box 1). 
Box 1. The final list of potential solutions for sustainable urban-rural linkages.

1. Gender inclusiveness

2. Promotion of effective decentralized system

3. Investment in basic and economic infrastructure

4. Investment in information communication and technology (ICT) facilities

5. Strengthening social ties

6. a. Adaptation to climate change

6. b. Mitigation of climate change

7. Promotion of modernized and sustainable agriculture systems

8. a. Establishment of small and medium scale industries

8. b. Establishment of large-scale industries

9. Protection of local producers and industries

10. Promotion and development of diversified livelihood systems

11. a. Social housing

11. b. Upgrading of slums

12. Establishment of human resource training centers

13. a. Innovative financial inclusion systems (including crop insurance, innovative sustainable credits, etc.)

13. b. Promoting value chain of waste management

13. c. Promoting value chain of agricultural commodities

14. a. Strategic location of higher educational institutions

14. b. Strategic refocusing of curricula at all levels

15. Effective land management systems

16. a. Promotion of sanitation and waste management practices

16. b. Promote grassroots policies on waste management

16. c. Policy on waste management separation

16. d. Manage waste as materials in transition (MINT)

17. Promotion and strengthening environmental governance

18. Afforestation and combating desertification

19. Establishment of economic growth poles

20. Incentives for responsible social behavior

Source: Authors (2019). Note a, b, c, d are sub potential solution.

In step 3, the prioritization process was applied by asking experts to rank the top 10 potential solutions while using the three pillars of sustainability (social, economic, and environmental) as the criteria for each solution contribution to development. The solutions were ranked from 1 to 10 , with the first solution being ranked with 10 points and the last solution ranked with one point. The ranked results were added together to create a total score given by equation 1 as the total score of all of the three pillars of sustainability. This study used the overall scores to prioritize the top five potential solutions.

$$
S u s_{t}=\sum_{i=1}^{n} S o_{j}+\sum_{i=1}^{n} E c_{j}+\sum_{i=1}^{n} E n_{j}
$$

where Sus $s_{t}$ is the total score for three components of sustainability, $S o_{j}$ is the sum of the social component scores, $E c_{j}$ is the sum of the economic component scores, $E n_{j}$ is the sum of the score of the environment for a given number ( $\mathrm{n}$ ) of respondents, and $j$ indicates the potential solutions.

Similar methodological approaches using the three pillars of sustainability have been applied when ranking forest plantations [50], assessing water resources management indicators [51], and ranking green building materials [52]. Different ranking processes have been used, and these include a pairwise comparison matrix [50], a hybrid of multi-criterial decision-making methods [52], and an assessment matrix [51]. Our methodological process adopted the simple ranking approach, which was appropriate because of the multi- and interdisciplinary nature of the participants (stakeholders).

In step 4, the top five potential solutions prioritized were elaborated upon giving specific examples of interventions. Only the top five solutions were dealt with due to time constraints during the third workshop held in Accra, Ghana, on 23-24 January 2019. An SDG interlinkages analysis was also performed for the top five potential solutions. The SDG interlinkages process and visualization 
identified the causal relationship of the 169 targets and their 232 trackable global SDG indicators from significant data sources, including the United Nations Sustainable Development SDG indicators database, the World Bank SDG database, and other United Nations databases [53]. A correlation analysis was performed on the identified and available indicators at the national level [53]. The correlation coefficients, which ranged from -1 to 1 , indicated the linear relationship between relevant targets. The positive coefficients represented positive linear relation (synergies) and the negative coefficients represented negative linear relations (trade-offs) [53]. The SDG interlinkages analysis and visualization using this method have been previously applied to Asian countries, including China, India, Japan, the Philippines, and Vietnam [53], but were yet to be applied in an African context.

In step 5, this study discussed the preliminary findings with a wider audience and experts at an international workshop that was hosted by the University of Tokyo in Japan on 17-18 March 2019, as a part of the validation process through feedback from the participants (Table 1). Experts were drawn from the Universities of Ghana, Cape Town, and Malawi, the University of Tokyo, the United Nations University Institute for the Advanced Study of Sustainability, the Institute for Global Environmental Strategies (IGES), and the Sustainability Science Consortium. The other participants were from JICA, the Development Bank of South Africa, and private, public, and civil societies.

\section{Results and Discussion}

\subsection{Challenges for Sustainable Urban-Rural Linkages}

This study found high inequality and gender gaps in the development of urban and rural areas in Ghana. The disparity was even higher from a gender perspective. We observed limited female participation in decision-making processes and the labor force, low secondary school enrolment, and high adolescent birth rates [54]. This study also found that social and economic systems in Ghana were not inclusive of equal female participation, which is of vital importance given that the female population in Ghana is $51.7 \%$, as compared to the male population of $48.3 \%$ [24].

This study noted poor basic and economic infrastructures, which was primarily due to increased rural-urban migration, urban sprawl, industrial expansion, and population increase in Ghana. These urban-rural challenges have contributed to the expansion of urban slum areas that have inadequate housing facilities. High rents translate into a lack of affordable housing. Slum communities face high exposure to risk and extreme-event disasters, such as flooding, and they have inadequate access to social and public services, including waste management and sanitation, education, and health [12]. Furthermore, low recycling rates, improper refuse disposal by households and commercial establishments, and poor burning practices exacerbate negative impacts on water quality and quantity, sanitation, health, and hygiene. For example, it is estimated that $16 \%$ of households have no electricity, $50 \%$ are without piped water, and $78 \%$ have no solid waste disposal mechanism in both urban and rural areas in Ghana [25]. Urban-rural connectivity is also weak as a result of poor and inadequate transport systems. Limited or absent information and communications technology (ICT) infrastructure in rural areas hampers effective health, education, communication, and business services. The urbanization rate in Ghana is 3.1\% yearly, which surpasses urban infrastructure improvement and services [25].

The limited effectiveness of decentralization at regional and district assemblies was primarily due to centralized decision-making and management and limited input from a local perspective $[36,55,56]$. The lack of local participation in development and governance weakens urban-rural linkages in a social, economic, and environmental context [36]. Decentralization was found to have led to institutional weakness, inefficient resource mobilization and utilization, inadequate human resource capacity, and poor performance [36,56].

Food and nutrition security dynamics are a challenge because of the ever-increasing urban population. Agriculture is the predominant source of livelihood for the rural community and it plays a vital role in national food security. However, limited economic power and availability of land, along with the impact of climate change, have led more people to migrate in the search of new 
livelihoods [10]. These migrants include young men, women, and children. Migrants face challenges in housing, access to health care and sanitation, trafficking, sexual abuse, exploitation, low salaries, and food insecurity although urban-rural remittances are one of the foremost contributors to rural household income and community development [25]. Consequently, a smaller number of farmers and producers have to meet the needs of a growing urban population. The increasing urban population affects the access to and the continuity, quality, and quantity of the food supply. Food insecurity is also linked to poverty, poor infrastructures, and socioeconomic instability, such as increasing numbers of female-headed households. The lack of access to affordable finance, funding for business ventures, technology, capacity building, and research/education tend to be among the core issues for weak urban-rural linkages. The poor have no capacity and collateral to borrow from banks at commercial rates, especially in rural areas.

\subsection{Ranking and Prioritized Potential Solutions}

The results revealed that gender inclusiveness was ranked first as a significant potential solution for enhancing sustainable urban-rural linkages $(n=20)$. The results also showed that the establishment of large-scale industries was the lowest ranked solution for strengthening sustainable urban-rural linkages (Figure 3). On the basis of the expert and stakeholder rankings $(n=20)$, the top five potential solutions (Figure 4) were gender inclusiveness, investment in economic infrastructures, modernization of agricultural systems, innovative financial inclusion, and the promotion of a decentralization system that is based on the total score.

\subsection{Elaboration and SDGs Interlinkage Analysis of the Prioritized Potential Solutions}

\subsubsection{Gender Inclusiveness}

In this study, gender inclusiveness refers to equal participation between males and females in economic, political, social, and cultural development, and decision-making on all issues in society [57]. Despite Ghana's increasing economic growth, gender inequality remains prevalent in the North and South Ghana, and in urban and rural areas [58]. The inclusion of gender considerations in all policy and decision-making processes is a critical step in reducing inequality in rural and urban centers. Addressing the gender gap has positive effects on migration patterns, food and water security, and education [25]. Studies show that $55 \%$ of hunger reduction in developing countries is associated with improvements in female education and the reduction of inequality [59].

Increasing public awareness regarding gender as a social construct could reduce the related cultural challenges that impede women's economic progress. This could be accomplished by incorporating gender and related issues in traditional curricula and by encouraging more proactive support by community heads and opinion leaders to positively reform the cultural and traditional roles of women [25]. The active participation of women would also provide holistic perspectives when identifying interventions or the solutions for community development.

Educational programs that target skills development and capacity building economically empower women. These educational programs could be achieved by providing training in financial literacy, business development, supply chain management, and technology (e.g., mobile banking and online trading).

For example, the marketing of products, such as groundnuts, or value-added products, such as shea butter, soap [60], and woven smocks, would improve income generation. The registration of women-owned small businesses as formal entities would also provide wider opportunities for expansion. Women in the agrarian sector could benefit from simple and affordable technologies to help them save time for other productive activities. Job-related skills development should be driven by community participation. A World Bank [61] program that transitions adolescent girls and young women from school to productive employment in Liberia, Rwanda, and South Sudan is an example of this. 


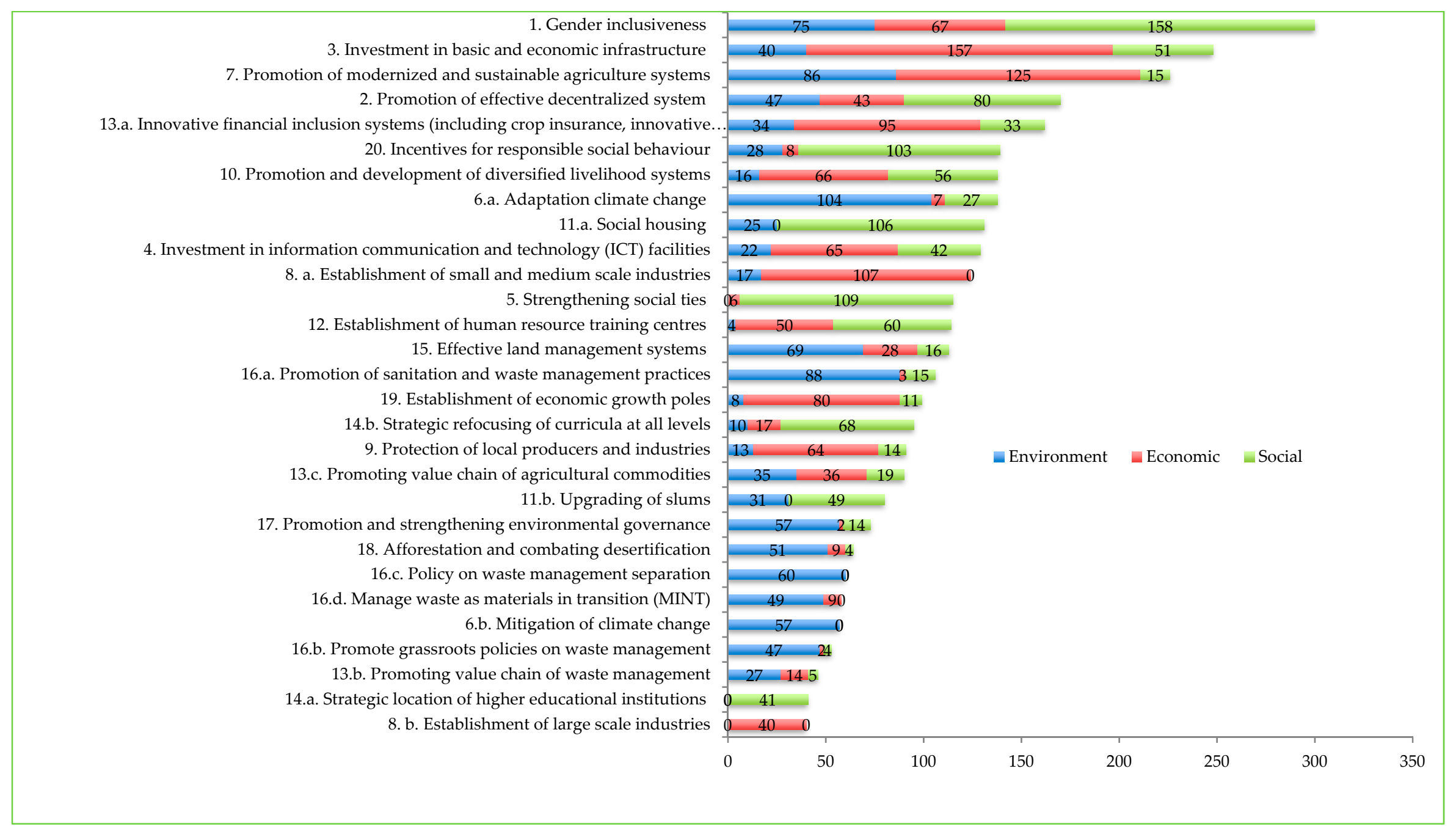

Figure 3. Priority(rank)-wise potential solutions for sustainable urban-rural linkages in Ghana. Source: Authors calculations (2019). 


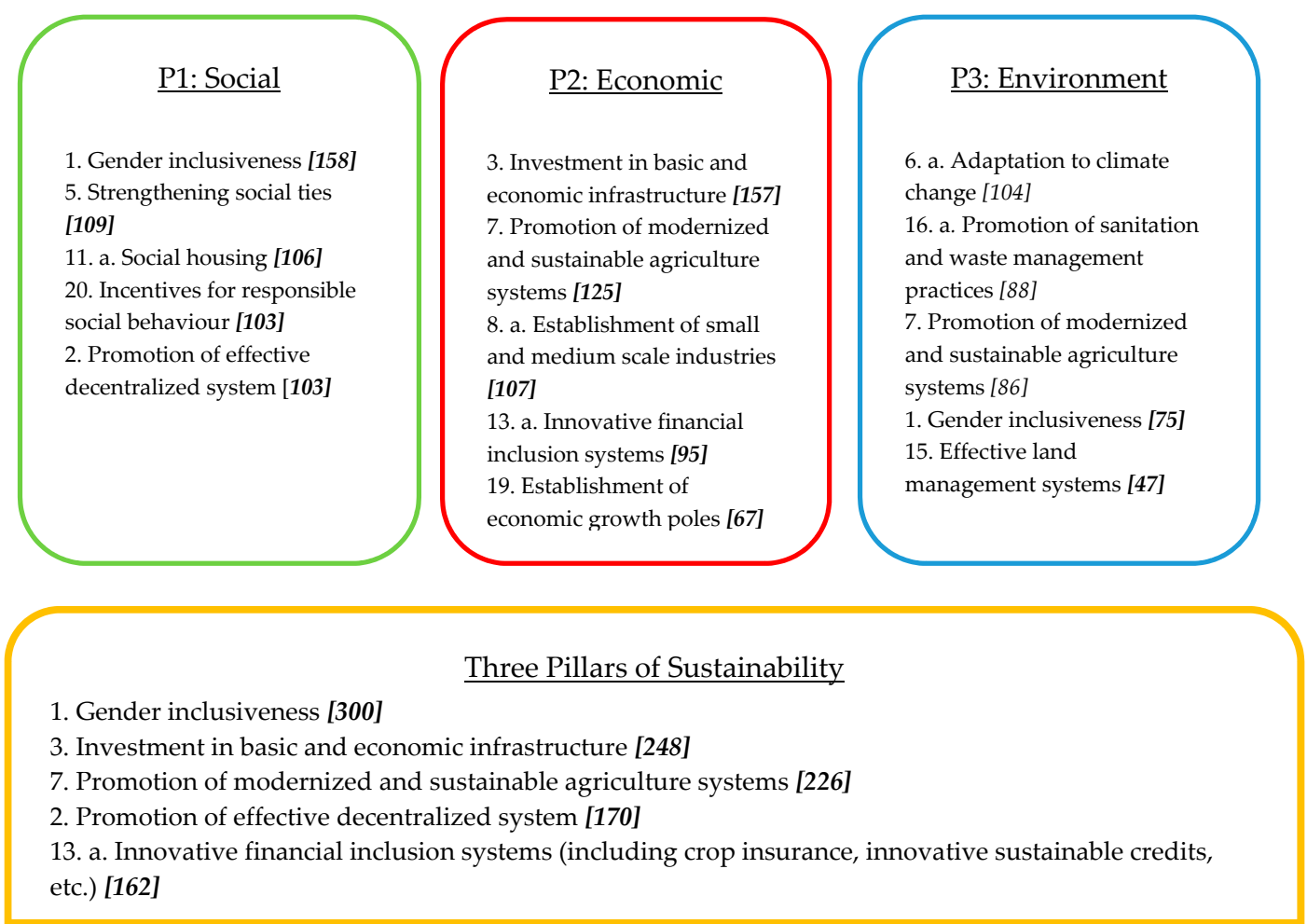

Figure 4. Top five potential solutions for sustainable urban-rural linkages in Ghana. Source: Authors calculations (2019).

Increased access to education for women and girls could be achieved through tertiary scholarships to help reduce early marriages; initiatives that help girls attend school full-time, such as affordable reusable sanitary pads [62,63]; and, return-to-school policies following childbirth [64].

Support for unpaid household and care work for women, especially in urban areas, could be achieved through institutional policies that subsidize unpaid care work and adjust working hours (e.g., reducing long hours or providing flexible or staggered working hours during) and by allowing women to work from home. The introduction of a paternity-leave scheme (currently not implemented in Ghana) and the provision of baby-care corners for mothers in the workplace could also help in achieving gender inclusiveness.

Gender inclusiveness is strongly related to the attainment of SDG 5 (gender equality), SDG 10 (reduce inequalities), and SDG 16 (peace, justice, and strong institutions). Gender inclusiveness appears to have strong positive impacts on SDGs 1 (end poverty), 2 (zero hunger), and 3 (good health and well-being) (Figure 5). It also has trade-offs with several targets, particularly SDGs 2 (zero hunger), 3 (good health and well-being), and 9 (industry innovation and infrastructure). Some of the synergies that could be accomplished through gender inclusiveness are in the agricultural sector. Women dominate the value chain, which accounts for the majority of women's livelihoods. In the infrastructure sector, women contribute to installations for health facilities, roads, markets, storage facilities, communication, and renewable energy. The trade-offs that are attributable to gender inclusiveness include the empowerment of women, which results in a shift from agriculture to other sectors and, therefore, a takeover of power and leadership from men. The lagging behind of the transport system and associated infrastructure might constrain the further enhancement of gender inclusion and should be urgently addressed. 


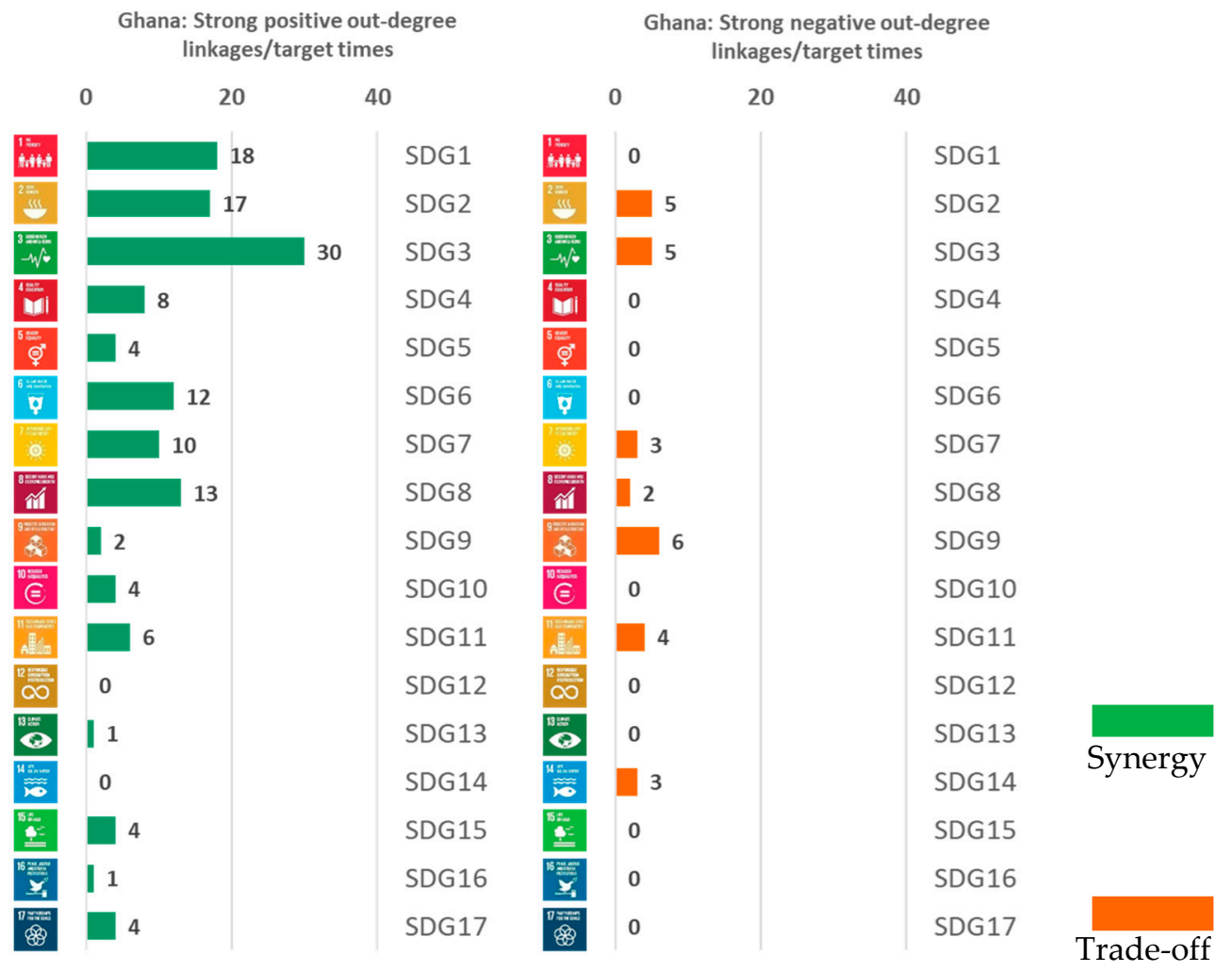

Figure 5. Strong positive (left) and strong negative (right) out-degree linkages between gender inclusiveness-related Sustainable Development Goal (SDG) targets and other targets. Source: Authors calculations using SDG interlinkages web tool developed by Institute for Global Environmental Strategies (IGES) and the data from United Nations Sustainable Development SDG indicators database and World Bank SDG database.

\subsubsection{Investment in Basic and Economic Infrastructures}

Food, water, health, education, housing, electricity, transportation, and communications are essential infrastructural components that are required for enhancing urban-rural linkages in Ghana [25] and they are critical resources for improving the livelihoods and general well-being across the country [35]. Attracting public-private partnerships (PPPs) is vital for leveraging the enormous cost of investment and technical skills required. Innovation and incentives for various local institutions, particularly the District Assembly (DA), could ensure added value to drive the PPP agenda to attract the private sector. The DA could generate its own funds, thereby reducing the reliance on the DA Common Fund, to support productive PPP arrangements. Equally important is ensuring that there are both social and economic infrastructure developments to achieve full benefits for human well-being, such as improving basic housing for slum dwellers, as well as for building coastal flood-control infrastructures [25].

Improving access to information is essential in strengthening public participation and ensuring complementary social and economic infrastructure development. Various methods of effective data collection and information sharing and feedback should be explored. Channels, such as social media, community information centers, and digital information hubs could be used, as well as social groups, like religious bodies. Institutions, such as the National Commission for Civic Education could also be strengthened through locally generated funds from civil society groups to support the dissemination of relevant information that would benefit the population.

The provision of physical infrastructures that are green, appropriate, sustainable, and affordable for meeting the needs of the population is important. In Ghana, opportunities are available through government initiatives, such as the one-district-one-factory policy, whereby improved storage facilities, 
integrated transportation systems (e.g., rail, road, and water), water-supply systems for irrigation and domestic use, and processing facilities for value addition can be explored. Urban green infrastructures could be promoted with integrated modern and traditional designs to maintain cultural and historical ties. Other considerations include sustainable, affordable housing, and coastal flood-control infrastructures. The compact-cities concept, whereby high-rise buildings are constructed to accommodate the urban population and maximize the land use for urban development, could also be considered. All of these solutions would require institutional collaboration and interlinkages in an integral approach.

This solution contributes to SDGs 9 (industry, innovation, and infrastructure) and 11 (sustainable cities and communities). Synergies are also strong with SDGs 2 (zero hunger), 6 (clean water and sanitation), 7 (affordable and clean energy), and 17 (partnerships for all goals). However, there are trade-offs with SDGs 3 (good health and well-being), 7 (affordable and clean energy), and 8 (decent work and economic growth). Producing a variety of by-products and utilizing waste should be actively promoted to achieve a significant impact on SDGs 12 (sustainable production and consumption) and 13 (climate action). Infrastructures that are related to solar, biomass production, and waste utilization would also reduce the negative aspects of SDG 7 (affordable and clean energy).

An example of an effort that would support SDG 17 (partnerships for all goals) is the multipurpose utilization of water resources, which would further SDGs 2 (zero hunger), 3 (good health and well-being), 6 (clean water and sanitation), 7 (affordable and clean energy), and 12 (sustainable production and consumption). A multipurpose dam is another example: a synergistic infrastructure that combines the contributions or achievements of SDGs 6 (clean water and sanitation) and 7 (affordable and clean energy). Building a dam for hydroelectricity and irrigation would be an investment in basic infrastructure that would also create positive support for SDG 8 (decent work and economic growth) by providing employment opportunities. The roads that are built for the power project could provide access to agricultural inputs and produce, markets, and storage facilities, thus improving the agricultural value chain. However, building infrastructures have negative impacts on the environment through deforestation and GHG emissions [65]. Ghana has underperformed on SDGs 9 (industry, innovation, and infrastructure) and 11 (sustainable cities and communities), according to the SDG Centre for Africa and Sustainable Development Solutions Network [66] progress report.

\subsubsection{Promotion of Modernized and Sustainable Agriculture Systems}

Sustainable agriculture is the management and preservation of food systems and natural resources through technological and institutional changes to meet the needs of current and future generations [67].

Increasing the awareness of opportunities in sustainable agriculture by all stakeholders, including women and young people, as well as the private sector, could be achieved through various innovative channels. For the youth, incorporating sustainable agriculture in the curricula at the Senior High School level and while using technologies, such as WhatsApp, Twitter, Facebook, and other social media, would make small-scale agricultural industries in rural areas more attractive and enhance people's perspectives. This is particularly true, given that modern agricultural systems address the challenges that are posed by climate change (low yield and costs) [25], land degradation, rapid urbanization, and demands from the growing population [35]. In Ghana, agriculture employs approximately $85 \%$ of the rural workforce, small-scale farmers produce $95 \%$ of the country's food crops, and of the 1.9 million hectares of potentially irrigable land, only $1.6 \%$ is exploited [68].

Training in modern, climate-smart, and sustainable technologies, supported by up-to-date and relevant research and data, would improve the skills and capacity of agricultural-extension-service providers and farmers in Ghana [25]. An organic agriculture approach, agro-forestry, and mechanization/ zero tillage systems are some successful examples of modernized agriculture [69]. The upscaling and strengthening of climate-smart agriculture strategies include improved and adaptive breeds/varieties, conservation agriculture, organic farming, agroforestry, sustainable urban agriculture, efficient smart-irrigation systems, mechanization of farm equipment, solar- or wind-powered equipment 
for off-grid farming, and affordable agricultural insurance. Furthermore, the promotion of agricultural processing and robust value-chain systems would ensure smooth production-consumption flows between urban and rural communities in Ghana [25].

The provision of effective and efficient research and an education extension system would improve the linkages between researchers, extension staff, and farmers for effective dissemination [70]. The integration of innovative technology platforms would enhance the efficiency of matching supply and demand for products and resources, such as animal production by Bovcontrol [71], the Integrated Agriculture Management Information System that was implemented by SMART Zambia Institute [72], Cure and Feed Livestock, e-Nutrifood, Weather and Crop Calendar, and AgriMarketplace [73]. Such examples could complement E-agricultural programs by the Ministry of Food and Agriculture in Ghana under the West African Agricultural Productivity Programme, ESOKO, and VODAFONE [73].

Sustainable agriculture has strong synergies with many SDGs, most notably SDGs 1 (no poverty), 2 (zero hunger), 3 (good health and well-being), 7 (affordable and clean energy), and 17 (partnership for all goals). Trade-offs are evident for the targets under SDGs 2 (zero hunger), 7 (affordable and clean energy), and 9 (industry innovation and infrastructure). Sustainable agricultural systems also have interlinkages with SDG 13 (climate action), 8 (decent work and economic growth), 9 (industry innovation and infrastructure), and SDG 17 (partnership for all goals). For example, policy harmonization has synergy with SDGs 16 (peace, justice, and strong institutions) and 17 (partnership for all goals), increased awareness and sustainable agricultural extension services reinforce SDG 4 (quality education), and institutional capacity has synergy with SDGs 1 (no poverty), 2 (zero hunger), 3 (good health), 11 (sustainable cities), 12 (responsible consumption and production), 13 (climate action), 15 (life on land), and 16 (peace, justice, and strong institutions). However, SDGs 2 (zero hunger) irrigation water and 6 (clean water and sanitation) have a trade-off with SDG 7 (affordable and clean energy) in terms of using water for hydro-power generation [74].

\subsubsection{Promotion of Effective Decentralized Systems}

This study found that decentralization encourages greater participation in the decision-making process (localization). A decentralized system was found to be more effective in maintaining urban-rural linkages when compared to a centralized one [25]. A decentralized governance system allows for local participation in decision-making processes, which is vital in sustaining effective rural-urban linkages [35] and strengthening local capacity and management (effective and efficient operationalization of existing regional and district administrative systems) of local affairs [75]. Local resource generation, planning, budgeting, and expenditure are areas that require strengthening in Ghana [25,75]. Decentralization is vital when it is used as an instrument for the development and engagement of all members of a society [75].

This potential solution has strong synergies between SDG 11 (sustainable cities and communities) and SDGs 6 (clean water and sanitation) and 15 (life on land), on which it would have strong positive impacts, and some targets under SDGs 11 (sustainable cities and communities), 12 (sustainable production and consumption), and 14 (life below water) may experience strong negative impacts. For example, the effective mobilization of local materials and human resources is key to local development [75]. However, the overexploitation of natural resources negatively impacts the environment.

\subsubsection{Innovative Financial Inclusion Systems}

Innovative and inclusive financial systems enhance people's capacity to participate in sustainable development [25]. Drawing the unbanked into formal financial systems enables people to have secure accounts and it supports savings, promotes transaction safety and transparency, and ultimately enables economic and political stability [76]. Services may be in the form of credits, crop insurance, and establishment of affordable, but reliable, channels of money transfer to enhance smooth remittance and cash flow. Current processes in the banking sector include digital banking (via the internet), mobile 
finance (savings, insurance, and credit), mobile banking (information and transactional), and mobile payments while using unified systems (person to person, business to business, and government to person) [77-79]. In Ghana, the number of adults ( +15 years) with mobile money accounts grew from $13 \%$ in 2014 to $39.8 \%$ in 2017 [78]. The growth rate within three years shows the potential for future mobile and digital financial inclusion in Ghana.

The promotion of increased access to affordable micro-financing, banking, and insurance for all is an essential factor in targeting inequality between the rich and poor, and between rural and urban populations [80]. Improving and strengthening private investment in the innovative use of ICT for mobile money banking and transfers might reduce inequality. Online banking is also cheaper than traditional cash transfers and it is easy to access in both urban and rural centers with connectivity. Policy initiatives should target micro-credit financing for entrepreneurs, especially youths and marginalized women, particularly in rural areas, where traditional banking facilities are not available [81]. Upscaling incentivizing innovations by most mobile telecommunication companies power most private innovative mobile financial services businesses in SSA $[82,83]$.

Innovative financial systems have strong synergies with SDGs 5 (gender equality), 10 (reduce inequalities), 12 (sustainable production and consumption), 9 (industry innovation and infrastructure), and 17 (partnership for all goals). For example, common platforms and interconnection between service providers (businesses) and all different users reduces the cost of business and enhances synergies. Financial inclusion has a significant role to play in ensuring that the urban-rural linkages are sustained. The benefits include the increase of individual savings and female empowerment, increased wealth creation, and increased consumption [84]. Furthermore, financial inclusion reduces the financial and personal risks, protects against shocks and stresses, increases security for aging populations, and guards against political and economic stability [84]. However, regulation fraud risk management and financial literacy are crucial in ensuring sustainable financial inclusion while using ICTs [77,83].

Disruptive technological innovations can help in reducing inequality and eradicating poverty, but these benefits (easy access and ICT based markets) may be at risk due to the uncertainty of policy and governance solutions. It is crucial that decision- and policy-makers understand the inner workings and impact of the technologies, the cost-effectiveness of including the population, the higher risk of default, the impacts on reliable credit systems [80], and the impact on inequality for those who are excluded in the transition. From an institutional standpoint, there are concerns that rules and regulations maintain the status quo of the wealthy and powerful and that technologies are localized and biased to benefit areas and locations that interest these groups $[85,86]$. These concerns give further importance to the development of robust financial inclusion policies. The introduction of technologies that are not backed by adequate regulatory frameworks might result in the failure of the systems. Reductions in bureaucracy to expand inclusion also engender legitimate concerns regarding fraud, money laundering, and financing of terrorism [80].

\section{Conclusions}

This study proposes a number of stepwise potential solutions to improve urban-rural linkages and development in Ghana. The solutions address the significant challenges of gender gaps, poor infrastructures, decentralization, affordable finance, and food security dynamics. The present study prioritizes the potential solutions with SDG interlinkages in a Ghanaian context. The key solutions, like gender, agriculture, infrastructure, decentralization, and financial inclusion, are identified as the most important factors for achieving social, economic, and environmental sustainability. Concisely, the gender inclusiveness is associated to addressing the challenges of cultural values, inequality, poverty and women's participation in education, economic, and governance processes. Investment in infrastructure enhances access to social services (housing, education, health) and economic services (input and output markets) for urban and rural development, as highlighted in the conceptual framework. Furthermore, the strengthening of climate-smart agriculture measures and promotion of modernized and sustainable agriculture systems enhance natural resource utilization and ecosystem 
services and improves local livelihoods, leading to less impact on rural-urban migration. The advancement of an effective decentralized systems is associated to the local participation and governance of environmental natural resources, social and economic service for sustainable urban and rural development. An innovative financial inclusion system increases access to affordable finance and an easy flow of remittances for improving economic opportunities for urban and rural development. These solutions are critical for resource allocation, development priority, and making positive impacts on sustainable urban-rural linkages. The SDG interlinkages that were specific to each solution were also shown to have synergies that can be maximized and trade-offs that can be avoided, which is critical for the allocation and efficient use of limited resources.

Some compelling challenges in the implementation process remain despite the practical application of the methodological approach demonstrated by the potential solutions generated for sustainable urban-rural linkages. In this study, the expert sample size was small at each stage of the process and the participants' judgments were subjective. Furthermore, the SDG interlinkages analysis could be improved with the availability of SDG data. The lack of SDG data is a challenge, as has been reported in the SDG Centre for Africa and Sustainable Development Solutions Network progress report [66]. This assessment was executed at the national level, and the results may be different at the local or regional level in Ghana.

We argue that the modified process framework used with the inclusion of four series of workshops, three pillars of sustainability, and SDG interlinkages in solution scanning is a practical and co-design approach (stakeholder participation) for developing potential policy actions [49,87]. The proposed methodology incorporates the principles of sustainability studies, such as being interdisciplinary, involving stakeholders, and creating core knowledge [49,87].

The adopted methodological framework has the potential for SDG interlinkages analysis for policy interventions beyond urban-rural linkages and it provides the potential solutions to the challenges of urban-rural linkages in Ghana as well as for other developing nations. A review on the progress of the implementation of the 2030 agenda, particularly on the urban-rural linkages [88], showed that some of our unique specific policies, such as working from home, paternity leave, the provision of baby-care corners in the workplace, and compact-cities concept, are currently not being implemented. Such specific solutions are valuable and they can be considered in a broader and specific decision-making process when producing specific policy interventions through a coordinated program of economic and social development policies 2017-2024 [25].

In addition to the practical approaches that were demonstrated by the results in this study, further research is required for better understanding the potential solutions that have not yet been explored. Further studies should consider a cost-benefit analysis for the local contextualization of the potential solutions identified.

Author Contributions: Conceptualization, O.S. and K.T.; methodology, G.M., A.M., C.G., A.N.S. and O.S.; software, X.Z. and M.M.; validation, G.M., A.M., O.S. and K.T.; formal analysis, G.M., X.Z. and M.M.; investigation, O.S., A.M., C.G., G.M. and A.N.S.; resources, K.T. and O.S.; data curation, O.S., J.L., G.M.; writing-original draft preparation, A.N.S.; writing-review and editing, A.N.S., G.M. and O.S.; visualization, X.Z. and M.M.; supervision, O.S.; project administration, O.S. and K.T.; funding acquisition, K.T. All authors have read and agreed to the published version of the manuscript.

Funding: The study was funded by the Japanese International Cooperation Agency (JICA) through the Development Strategy for Urban Sustainability in Africa on the Basis of SDGs Interlinkage Analysis (USiA) Project, University of Tokyo, Japan. The first author was grated scholarship by Japan Foundation for United Nations University (jfUNU). United Nations University Institute for the Advanced Study of Sustainability (UNU-IAS) has paid APC.

Acknowledgments: We acknowledge the support from different institutions, which include; Japanese International Cooperation Agency (JICA), University of Ghana, University of Development Studies, The University of Tokyo, United Nations University Institute for the Advanced Study of Sustainability (UNU-IAS) and Institute for Global Environmental Strategies (IGES).

Conflicts of Interest: The authors of the article declare that they have no conflict of interest. The sponsors had no role in the design, execution, interpretation, or writing of the study. 


\section{References}

1. United Nations Department of Economic and Social Affairs (UNDESA). World Urbanization Prospects; UDESA Population Division: New York, NY, USA, 2018.

2. Von Braun, J. Rural-Urban Linkages for Growth, Employment and Poverty Reduction. In Proceedings of the Fifth International Conference on the Ethiopian Economy, Addis Ababa, Ethiopia, 7-9 June 2007; p. 22.

3. Showers, K.B. Water scarcity and urban Africa: An overview of urban-rural water linkages. World Dev. 2002, 30, 621-648. [CrossRef]

4. Tacoli, C. Changing Rural-Urban Interactions in Sub-Saharan Africa and their Impact on Livelihoods: A Summary; International Institute for Environment and Development (IIED): London, UK, 2002; p. 34.

5. Tacoli, C. The links between urban and rural development. Environ. Urban. 2003, 15, 3-12. [CrossRef]

6. Tacoli, C.; McGranahan, G. Urbanisation, Rural-Urban Migration and Urban Poverty; International Institute for Environment and Development (IIED): London, UK, 2015; p. 28.

7. Imai, K.S.; Gaiha, R.; Garbero, A. Poverty reduction during the rural-urban transformation: Rural development is still more important than urbanisation. J. Policy Model. 2017, 39, 963-982. [CrossRef]

8. United Nations. The Sustainable Development Goals Report; United Nations: New York, NY, USA, 2017.

9. Frayne, B. Migration and urban survival strategies in Windhoek, Namibia. Geoforum 2004, 35, 489-505. [CrossRef]

10. Barrios, S.; Bertinelli, L.; Strobl, E. Climatic change and rural-urban migration: The case of sub-Saharan Africa. J. Urban Econ. 2006, 60, 357-371. [CrossRef]

11. Owuor, S.O. Development Southern Africa Migrants, urban poverty and the changing nature of urban-rural linkages in Kenya Migrants, urban poverty and the changing nature of urban-rural linkages in Kenya. Dev. S. Afr. 2007, 34, 109-122. [CrossRef]

12. Awumbila, M.; Owusu, G.; Teye, J.K. Can Rural-Urban Migration into Slums Reduce Poverty? Evidence from Ghana. In Working Paper No 13; Migrating Out of Poverty Research Programme Consortium: Sussex, UK, 2014; pp. 1-41.

13. de Brauw, A.; Mueller, V.; Lee, H.L. The role of rural-urban migration in the structural transformation of Sub-Saharan Africa. World Dev. 2014, 63, 33-42. [CrossRef]

14. Brueckner, J.K.; Lall, S.V. Cities in Developing Countries. Fueled by Rural-Urban Migration, Lacking in Tenure Security, and Short of Affordable Housing. Handb. Region. Urban Econ. 2015, 5, 1399-1455. [CrossRef]

15. Kleemann, J.; Inkoom, J.N.; Thiel, M.; Shankar, S.; Lautenbach, S.; Fürst, C. Peri-urban land use pattern and its relation to land use planning in Ghana, West Africa. Landsc. Urban Plan. 2017, 165, 280-294. [CrossRef]

16. Ghana Statistical Service (GSS). 2010 Population and Housing Census; Ghana Statistical Service: Accra, Ghana, 2012.

17. Akkoyunlu, S. The Potential of Rural-urban Linkages for Sustainable Development and Trade. Int. J. Sustain. Dev. World Policy 2015, 4, 20-40. [CrossRef]

18. Djurfeldt, A.A. Urbanization and linkages to smallholder farming in sub-Saharan Africa: Implications for food security. Glob. Food Sec. 2015, 4, 1-7. [CrossRef]

19. Berdegué, J.A.; Carriazo, F.; Jara, B.; Modrego, F.; Soloaga, I. Cities, Territories, and Inclusive Growth: Unraveling Urban-Rural Linkages in Chile, Colombia, and Mexico. World Dev. 2015, 73, 56-71. [CrossRef]

20. Satterthwaite, D.; Tacoli, C. The Role of Small and Intermediate Urban Centres in Rural Development: Assumptions and Evidence. In The Earthscan Reader in Rural-Urban Linkages; Tacoli, C., Ed.; International Institute for Environment and Development: London, UK, 2006; pp. 155-184.

21. International Monetary Fund (IMF). Sub-Saharan Africa: The Path to Recovery. Available online: https: //www.imf.org/en/News/Articles/2017/10/27/na103017-sub-saharan-africa-the-path-to-recovery (accessed on 11 May 2018).

22. Brundtland, G.H. Our Common Future: Report of the World Commission on Environment and Development; United Nations: New York, NY, USA, 1987; pp. 30-60.

23. Purvis, B.; Mao, Y.; Robinson, D. Three pillars of sustainability: In search of conceptual origins. Sustain. Sci. 2019, 14, 681-695. [CrossRef]

24. Ghana Statistical Service (GSS). Ghana Living Standards Survey Round 6 (GLSS 6); Ghana Statistical Service: Accra, Ghana, 2014. 
25. National Development Planning Commission (NDPC). The Coordinated Programme of Economic and Social Development Polices 2017-2024. An Agender for Jobs: Creating Prosperity and Equal Oppotunities for All; NDPC: Accra, Ghana, 2017; pp. 80-93.

26. Nyame, F.K.; Grant, J.A.; Yakovleva, N. Perspectives on migration patterns in Ghana's mining industry. Resour. Policy 2009, 34, 6-11. [CrossRef]

27. Abu, M.; Codjoe, S.N.A.; Sward, J. Climate change and internal migration intentions in the forest-savannah transition zone of Ghana. Popul. Environ. 2014, 35, 341-364. [CrossRef]

28. Christiaensen, L.; Todo, Y. Poverty reduction during the rural-urban transformation - The role of the missing middle. World Dev. 2013, 63, 43-58. [CrossRef]

29. Schlesinger, J.; Drescher, A.; Shackleton, C.M. Socio-spatial dynamics in the use of wild natural resources: Evidence from six rapidly growing medium-sized cities in Africa. Appl. Geogr. 2015, 56, 107-115. [CrossRef]

30. Crush, J.; Caesar, M. Food Remittances: Migration and Food Security in Africa; Balsillie School of International Affairs: Waterloo, ON, Canada, 2016.

31. Vandercasteelen, J.; Beyene, S.T.; Minten, B.; Swinnen, J. Cities and agricultural transformation in Africa: Evidence from Ethiopia. World Dev. 2018, 105, 383-399. [CrossRef]

32. Ward, C.D.; Shackleton, C.M. Natural Resource Use, Incomes, and Poverty Along the Rural-Urban Continuum of Two Medium-Sized, South African Towns. World Dev. 2016, 78, 80-93. [CrossRef]

33. Mars, M. Telemedicine and advances in urban and rural healthcare delivery in Africa. Prog. Cardiovasc. Dis. 2013, 56, 326-335. [CrossRef]

34. Adam, C.; Bevan, D.; Gollin, D. Rural-urban Linkages, Public Investment and Transport Costs: The Case of Tanzania. World Dev. 2018, 109, 497-510. [CrossRef]

35. Simon, D.; McGregor, D.; Nsiah-Gyabaah, K. The changing urban-rural interface of African cities: Definitional issues and an application to Kumasi, Ghana. Environ. Urban. 2004, 16, 235-248. [CrossRef]

36. Owusu, G. Small Towns in Ghana: Justifications for their Promotion under Ghana's Decentralisation Programme. Afr. Stud. Q. 2005, 8, 48-68.

37. Victor, O.U.; Hope, E.N. Rural-Urban 'Symbiosis', community self-help, and the new planning mandate: Evidence from Southeast Nigeria. Habitat Int. 2011, 35, 350-360. [CrossRef]

38. Duraiappah, A.K.; Asah, S.T.; Brondizio, E.S.; Kosoy, N.; O’Farrell, P.J.; Prieur-Richard, A.; Subramanian, S.M.; Takeuchi, K. Managing the mismatches to provide ecosystem services for human well-being: A conceptual framework for understanding the New Commons. Curr. Opin. Environ. Sustain. 2014, 7, 94-100. [CrossRef]

39. Tacoli, C. Rural-Urban Linkages and Pro-Poor Agricultural Growth: An Overview. In Proceedings of the POVNET Workshop on Agriculture and Pro-Poor Growth, Helsink, Finland, 17-18 June 2004; pp. 1-17.

40. Farrington, J. Policy Planning and Implementation: Rural-Urban Linkages. In ODI Series 10; Department for International Development: London, UK, 2002.

41. United Nations. New Urban: Agenda; United Nations: New York, NY, USA, 2017.

42. International Food Policy Research Institute (IFPRI). Global Food Policy Report 2017; IFPRI: Washington, DC, USA, 2017.

43. Gren, Å.; Andersson, E. Being efficient and green by rethinking the urban-rural divide—Combining urban expansion and food production by integrating an ecosystem service perspective into urban planning. Sustain. Cities Soc. 2018, 40, 75-82. [CrossRef]

44. Zewdu, G.A.; Malek, M. Implications of Land Policies for Rural-urban Linkages and Rural Transformation in Ethiopia. Working Paper No. 15 2010, 32. Available online: https://www.ifpri.org/publication/implicationsland-policies-rural-urban-linkages-and-rural-transformation-ethiopia (accessed on 2 June 2019).

45. Sutherland, W.J.; Gardner, T.; Bogich, T.L.; Bradbury, R.B.; Clothier, B.; Jonsson, M.; Kapos, V.; Lane, S.N.; Moeller, I.; Schroeder, M.; et al. Solution Scanning as a Key Policy Tool: Identifying Management Interventions to Help Maintain and Enhance Regulating Ecosystem Services. Ecol. Soc. 2014, 19, 3. [CrossRef]

46. Hernández-Morcillo, M.; Burgess, P.; Mirck, J.; Pantera, A.; Plieninger, T. Scanning agroforestry-based solutions for climate change mitigation and adaptation in Europe. Environ. Sci. Policy 2018, 80, 44-52. [CrossRef]

47. Dicks, L.; Haddaway, N.; Hernández-Morcillo, M.; Mattsson, B.; Randall, N.; Failler, P.; Ferretti, J.; Livoreil, B.; Saarikoski, H.; Santamaria, L.; et al. Knowledge Synthesis for Environmental Decisions: An Evaluation of Existing Methods, and Guidance for their Selection, Use and Development: A Report from the EKLIPSE Project; European Union: Brussels, Belgium, 2017; pp. 20-30. 
48. Pullin, A.; Sutherland, W.; Gardner, T.; Kapos, V.; Fa, J. Conservation priorities: Identifiying need, taking action and evaluating success. Key Top. Conserv. Biol. 2013, 2, 3-22.

49. Sugiyama, M.; Asayama, S.; Kosugi, T.; Ishii, A.; Emori, S.; Adachi, J.; Akimoto, K.; Fujiwara, M.; Hasegawa, T.; Hibi, Y.; et al. Transdisciplinary co-design of scientific research agendas: 40 research questions for socially relevant climate engineering research. Sustain. Sci. 2017, 12, 31-44. [CrossRef]

50. Diaz-Balteiro, L.; Alfranca, O.; González-Pachón, J.; Romero, C. Ranking of industrial forest plantations in terms of sustainability: A multicriteria approach. J. Environ. Manag. 2016, 180, 123-132. [CrossRef] [PubMed]

51. Pires, A.; Morato, J.; Peixoto, H.; Botero, V.; Zuluaga, L.; Figueroa, A. Sustainability Assessment of indicators for integrated water resources management. Sci. Total Environ. 2017, 578, 139-147. [CrossRef] [PubMed]

52. Khoshnava, S.M.; Rostami, R.; Valipour, A.; Ismail, M.; Rahmat, A.R. Rank of green building material criteria based on the three pillars of sustainability using the hybrid multi criteria decision making method. J. Clean. Prod. 2018, 173, 82-99. [CrossRef]

53. Zhou, X.; Moinuddin, M. Sustainable Development Goals Interlinkages and Network Analysis: A Practical Tool for SDG Integration and Policy Coherence; Institute for Global Environmental Strategies: Tokyo, Japan, 2017; p. 140.

54. United Nations Statistics Division (UNSD). The United Nations Minimum Set of Gender Indicators. United Nations, 2019. Available online: https://genderstats.un.org/\#/home (accessed on 2 June 2019).

55. Owusu, G. The role of district capitals in regional development - Linking small towns, rural-urban linkages and decentralisation in Ghana. Int. Dev. Plan. Rev. 2005, 27, 59-89. [CrossRef]

56. Antwi, K.B.; Analoui, F. Challenges in building the capacity of human resource development in decentralized local governments: Evidence from Ghana. Manag. Res. News 2008, 31, 504-517. [CrossRef]

57. Mukhopadhyay, M. Mainstreaming Gender or 'Streaming' Gender Away: Feminists Marooned in the Development Business. In The Palgrave Handbook of Gender and Development; Palgrave Macmillan: London, UK, 2016; pp. 77-91. [CrossRef]

58. Osei-Assibey, E. Nature and Dynamics of Inequalities in Ghana. Development 2014, 57, 521-530. [CrossRef]

59. United Nations Women. Climate Change, Gender and Food Security in the Pacific; United Nations: Suva, Fiji, 2014.

60. Jasaw, G.S.; Saito, O.; Gasparatos, A.; Shoyama, K.; Boafo, Y.A.; Takeuchi, K. Ecosystem services trade-offs from high fuelwood use for traditional shea butter processing in semi-arid Ghana. Ecosyst. Serv. 2017, 27, 127-138. [CrossRef]

61. World Bank. Adolecent Girls Initiatives. 2014. Available online: https://www.worldbank.org/en/programs/ adolescent-girls-initiative (accessed on 2 June 2019).

62. Mauran, C. Reusable Sanitary Pads Help East. African Girls in School. Period. 2018. Available online: https://unreasonablegroup.com/articles/reusable-sanitary-pads-keep-east-african-girls-in-school/ (accessed on 2 June 2019).

63. Lumutenga, N.; Khaitsa, M.; Muwazi, R.; Wakoko-Studstill, F.; Naigaga, I.; Hossfeld, L.; Ralston, M. Women Empowering Women Through Reusable Sanitary Pads. J. Community Engagem. Scholarsh. 2017, 10, 15.

64. Wendekind, V.; Milingo, T. Second Chances for Girls: The Zambian Re-Entry into School Policy. In Time to Learn Case Study Series; USAID: Washington, DC, USA, 2015.

65. Bebbington, A.J.; Bebbington, D.H.; Sauls, L.A.; Rogan, J.; Agrawal, S.; Gamboa, C.; Imhof, A.; Johnson, K.; Rosa, H.; Royo, A. Resource extraction and infrastructure threaten forest cover and community rights. Proc. Natl. Acad. Sci. USA 2018, 115, 52. [CrossRef]

66. SDG Center for Africa and Sustainable Development Solutions Network. Africa SDG Index and Dashboards Report 2019; SDG: New York, NY, USA, 2019.

67. Food and Agriculture Organizaion (FAO). Dimensions of Need-Sustainable Agriculture and Rural Development; FAO: Rome, Italy, 1995.

68. Food and Agriculture Organizaion (FAO). Ghana: Irrigation Market Brief; FAO: Rome, Italy, 2014.

69. Horlings, L.G.; Marsden, T.K. Towards the real green revolution? Exploring the conceptual dimensions of a new ecological modernisation of agriculture that could 'feed the world'. Glob. Environ. Chang. 2011, 21, 441-452. [CrossRef]

70. Abunga, M.; Emelia, G.; Samuel, D. Adoption of modern agricultural production technologies by farm households in Ghana: What factors influence their decisions? J. Biol. Agric. Healthc. 2012, 2, 1-14.

71. Bovcontrol. A Data Collection and Analysis Tool to Improve Performance on Meat, Milk and Genetics Production. Available online: https://www.bovcontrol.com (accessed on 16 July 2019). 
72. SMART Zambia Institute. The Zambia Integrated Agriculture Management Information System (ZIAMIS). Available online: https:/www.szi.gov.zm/ziamis/ (accessed on 1 August 2019).

73. Food and Agriculture Organizaion (FAO). FAO Launches Four New Agricultural Service Apps in Africa. E-Agriculture. Available online: http://www.fao.org/e-agriculture (accessed on 16 July 2019).

74. Weitz, N.; Nilsson, M.; Davis, M. A Nexus Approach to the Post-2015 Agenda: Formulating Integrated Water, Energy, and Food SDGs. SAIS Rev. Int. Aff. 2014, 34, 37-50. [CrossRef]

75. Nyendu, M. Democratic Decentralization in Ghana: The Need for a Policy Review. J. Asian Afr. Stud. 2012, 47, 221-235. [CrossRef]

76. Consultative Group to Assist the Poor (CGAP). Donors and Investors: Funding Instruments. Consultative Group to Assist. the Poor-CGAP: Focus Areas. Available online: http://www.cgap.org/topics/fundinginstruments (accessed on 9 June 2019).

77. Gencer, M. The Mobile Money Movement: Catalyst to Jump-Start Emerging Markets. Innov. Technol. Gov. Glob. 2011, 6, 101-117. [CrossRef]

78. World Bank. Ghana: Agriculture Sector Policy Note: Transforming Agriculture for Economic Growth, Job Creation, and Food Security; World Bank: Washington, DC, USA, 2017; p. 63.

79. World Bank. Global Financial Development Report 2014: Financial Inclusion; World Bank: Washington, DC, USA, 2014.

80. Allen, F.; Demirguc-Kunt, A.; Klapper, L.; Peria, M.S.M. Foundations of Financial Inclusion: Understanding Ownership and Use of Formal Accounts; World Bank: Washington, DC, USA, 2012. [CrossRef]

81. Morawczynski, O. Surviving in the 'dual system': How M-PESA is fostering urban-to-rural remittances in a Kenyan Slum. In Proceedings of the IFIP WG 9.4-University of Pretoria Joint Workshop, Pretoria, South Africa, 23-24 September 2008; pp. 110-147.

82. Aker, J.C.; Mbiti, I.M. Mobile Phones and Economic Development in Africa. SSRN Electron. J. 2010, 24, 207-232. [CrossRef]

83. Donovan, K. Mobile Money for Financial Inclusion. In Information and Communications for Development; World Bank: Washington, DC, USA, 2012; pp. 61-74. [CrossRef]

84. Akudugu, M.A. The determinants of financial inclusion in Western Africa: Insights from Ghana. Res. J. Financ. Account. 2013, 4, 1-10.

85. Glowacki-Dudka, M. Book Review: The Third Industrial Revolution: How Lateral Power Is Transforming Energy, the Economy, and the World. Adult Learn. 2013, 24, 50-51. [CrossRef]

86. Acemoglu, D. Localised and Biased Technologies: Atkinson and Stiglitz's New View, Induced Innovations, and Directed Technological Change. Econ. J. 2015, 125, 443-463. [CrossRef]

87. Komiyama, H.; Takeuchi, K. Sustainability science: Building a new discipline. Sustain. Sci. 2006, 1, 1-6. [CrossRef]

88. National Development Planning Commission. Ghana: Voluntary National Review Report on the Implementation of the 2030 Agenda for Sustainable Development; NDPC: Accra, Ghana, 2019; pp. 60-95. 